\title{
Design of a blended learning environment: Considerations and implementation issues
}

\author{
Nuray Gedik \\ Akdeniz University, Turkey \\ Ercan Kiraz and M. Yasar Ozden \\ Middle East Technical University, Turkey
}

This study identified critical issues in the design of a blended learning environment by examining basic design considerations and implementation issues. Following a designbased research approach with the phenomenological tradition of qualitative research, the study investigated instructor experiences relating to the design, development, and implementation processes of a blended course. The results reveal that the design considerations centred on the pedagogical approach, course organization, materials preparation, interactions, and the instructor's and students' roles. The affordances of the implementation included the arousal of the students' interest and participation, flexibility, time conservation, the ability to track student progress, and the improvement of interaction, collaboration, and communication opportunities. The challenges were increased workload, course and time management, overlaps, and the creation of harmony between the face-toface and online environments. The overall results show that the critical issues involved context, the pedagogical framework, instructor competency, and technical issues in the blended course design.

\section{Introduction}

The advent and exponential growth of the Internet has resulted in new trends and uses of learning environments. Online learning is a term commonly used to refer to usage of the Internet or the World Wide Web (WWW) to enhance learning and teaching. Following the integration of face-to-face (F2F) learning experiences and online learning, 'blended learning' (BL) attracted great interest from researchers and educational institutions, who sought to benefit from the advantages provided by both environments (Allen, Seaman, \& Garrett, 2007). Graham (2006) provided a definition that embraces the common use of this term as a system: "Blended learning systems combine face-to-face instruction with computermediated instruction" (p. 5). In a higher education context, BL also has been called an "evolutionary transformation" (Garrison \& Vaughan, 2008) due to the availability of Web-based systems in universities, and because it provides more interaction with students in large classes and more flexible learning environments in terms of economic and administrative considerations (Bates \& Poole, 2003; Garnham \& Kaleta, 2002; Singh, 2003). Supporting these expectations, the 2009 meta-analysis of the US Education Department reported the results of a comparison of blended learning with F2F and online instruction. The conclusion was that "Instruction combining online and face-to-face elements had a larger advantage relative to purely face-to-face instruction than did purely online instruction" (Means, Toyama, Murphy, Bakia, \& Jones, 2009, p. xvii).

It can be argued that designing a BL environment (BLE) is not as simple as combining an online environment with a F2F course. Beyond that basic integration, the selection of a best environment for implementation is also required. This is why it is important to distinguish BL design from technology enhanced or online supported course design (Garrison \& Kanuka, 2004, p. 97). Hofmann (2002) explained a main lesson taken from a BL experience in the context of a training setting: "re-creating learning online and determining the right blend isn't easy or to be taken lightly" (p. 519). This observation is also valid concerning the use of BL in the sphere of higher education. A great deal of consideration is needed beyond the stage of simply combining online and F2F practices if a BL experience is to be successful. How then does one effectively design instruction in BLEs? The present study was intended to contribute data to answer this question.

In instructional design decisions and implementations, pedagogical frameworks help instructors not only to specify the elements of the course, but also to provide a solid base from which to build the technology 
and approaches. In this study, two pedagogical frameworks were used: Merrill's (2002) First Principles of Instruction and authentic learning. Merrill's (2002) framework included the following principles for the instructional design (pp. 44-45):

- Learning is promoted when learners are engaged in solving real-world problems

- Learning is promoted when existing knowledge is activated as a foundation for new knowledge

- Learning is promoted when new knowledge is demonstrated to the learner

- Learning is promoted when new knowledge is applied by the learner

- Learning is promoted when new knowledge is integrated into the learner's world

Merrill (2007) argued that learning is facilitated when (pp. 63-64):

- the instruction directs learners to recall, relate, describe, or apply knowledge from relevant past experience that can be used as a foundation for the new knowledge [activation]

- the next activity in a learning cycle demonstrates the new knowledge to be learned, rather than merely telling information about the new learning [demonstration]

- the third activity in a learning cycle provides opportunity for learners to apply the new knowledge to new specific situations [application]

- $\quad$ the instruction provides an opportunity for learners to publicly demonstrate their newly acquired knowledge and skill; ... to reflect on, discuss, or defend their new knowledge, and ... to create, invent, or explore new and personal ways to use their new knowledge and skill [integration]

- the student is shown a problem, taught the components, and then shown how the components are used to solve the problem or do the whole task [problem]

With the use of "coherent, meaningful, and purposeful" activities (Brown, Collins, \& Duguid, 1989, p. 34) to support students' learning, authentic learning environments aim to immerse learners in the cognitive demands of a real environment (Savery \& Duffy, 1995). Authenticity in learning environments is promoted by a number of researchers due to its ability to help learners to transfer theoretical knowledge to the real-world, and hence, to create a meaningful learning context (Grabinger, 1996; Herrington \& Oliver, 2000; Jonassen, 1999). Rooted by situated cognition or situated learning and anchored instruction, authentic learning required the engagement of learners in an "inventive and realistic task that provides opportunities for complex collaborative activities" (Herrington, Reeves, Oliver, 2010, p. 1). The affordances of blended learning for using real-life problems and supporting learners and their interactions are regarded as supports for authentic learning activities (Oliver, Herrington, \& Reeves, 2006). Authentic learning activities share the following features aided by the elements of blended learning approach (pp. 512):

- Have real world relevance

- Are ill defined, requiring students to define the tasks and subtasks needed to complete the activity

- Provide the opportunity for students to examine the task from different perspectives, using a variety of resources

- Provide the opportunity to collaborate

- Provide the opportunity to reflect and involve students' beliefs and values.

As Herrington, Reeves, Oliver, and Woo (2004) noted, the design of authentic environments must be informed by an analysis of the critical characteristics that help to enhance learning. Exploration of the effects and design of BLEs is also believed to be necessary in order to achieve more meaningful learning experiences (Bliuc, Goodyear, \& Ellis, 2007; Garrison \& Kanuka, 2004). Although the focus was not on student learning, the current study aimed to portray critical issues in the design of BLEs by investigating design considerations, and issues in the course implementation process in terms of affordances and challenges for the instructor using the BLE. The study investigated this topic from an instructor's perspective. The research questions that guided the study were the following:

What are the design considerations?

- What are the affordances that assist the instructor using a BLE during a course implementation?

- What are the challenges for the instructor regarding the use of a BLE during a course implementation? 


\section{Method}

\section{Design of the study}

Two frameworks were used in the study design. As an outer framework, the Design-Based Research (DBR) approach was used to study important issues in the BL design process, and those which arose during the implementation period. This contributed to the discovery of ways to improve the design in practice (Collins, Joseph, \& Bielaczyc, 2004; Design-Based Research Collective, 2003; McKenney, Nieveen, \& van den Akker, 2006; Reeves, Herrington, \& Oliver, 2005). As Willis (2008) pointed out, the DBR "tries to solve a local problem by designing effective instructional resources or procedures while also trying to create knowledge that has a broader application than the local context" (p. 323). Given that BL design is very context-dependent (Harris, Connolly, \& Feeney, 2009), the researchers employed the DBR within a specific context to investigate the BL design process in all stages. Rich data from the participants' natural setting over a long period was thereby acquired. Within the DBR framework, phenomenology in the form of heuristic inquiry was used in the data collection, analysis, and interpretation procedures to elicit the meanings of the instructor experiences. Heuristic inquiry is a form of phenomenological inquiry that allows the researcher to include his/her own personal experiences and insights in order to describe the experiential meanings of lived experiences (Moustakas, 1990; Patton, 2002; van Manen, 1990). Utilizing a heuristic design as a second framework allowed the researchers to identify the personal insights gained within the context of a BL course.

\section{Participants}

The participants were the course instructor, who was the first author of this study, and three participants (Peers A, B, and C), who were teaching assistants in an IT related department (two males and one female). The primary researcher's insider role provided her with the "opportunity to learn directly from [her] own experience of the setting" (Marshall \& Rossman, 1999, p. 106) and helped her to reflect on the personal insights within a heuristic inquiry process (Douglass \& Moustakas, 1985). Being familiar with BLEs, all of the peers observed the F2F environment during different hours, and visited the online environment as guests to explore how the students and instructor used the environment. Only one peer and the course instructor had previously used the LMS.

\section{Role of the Researchers}

The first author took primary responsibility for the research, including designing and implementing the study and the other researchers acted as consultants. The lead researcher took two roles in this study: first, she was a data source herself as the course instructor, and second, she was a participant observer. Prior to this study, she had not taught any courses with an online component. Although she had taken many graduate courses on the theoretical uses of Internet technologies as supports for F2F courses, she did not have prior practical experience as an instructor. It is commonly accepted that being part of the study increases a researcher's openness and understanding of the nature of the study, and hence, helps with the meaning-making process (Patton, 2002).

The fellow researchers provided the lead researcher with continuous feedback on every step of the research. They offered feedback to the first author during the data analysis and interpretation stages (i.e., the first author made the analyses and reported the findings, and then the fellow researchers gave feedback on the interpretations). Therefore, the resulting interpretations are the common ones that were made by all authors.

\section{Data collection and analysis}

Data were collected from the instructor's diary, the peers' observation notes, interviews of the peers, and course related documents. The data collection process is shown in summary form in Figure 1.

For the data analysis, an inductive coding scheme was used within a systematic process to analyse the data without predefined codes. Initially, descriptive codes and notes were placed in the margins of the pages to classify and identify the data. Then, the coded data was sorted into categories to generate themes. After this first-level of coding, all the categories from each data source were grouped under major themes 
related to the scope of the research questions. In the peer interview analyses, qualitative analysis software was used (QSR Nvivo 8), which eased the processes of coding, grouping, and organizing data into categories and themes. The rest of the written documents were analysed by hand using the procedure above. The common themes were then grouped into generalizations and synthesized into final themes. While identifying common themes, it was attempted to discover the phenomenological essences of the experiences, as Moustakas (1994) suggested. For this purpose, significant statements were identified throughout the analysis process and stored for later use.

\section{Trustworthiness}

Given that the lead researcher's insights and personal experiences were included as data in the study, this might appear to affect the trustworthiness of the research. But that inclusion offered certain advantages. First of all, having a qualitative researcher as a member of the setting allowed "to experience what it is like to be in that setting" (Patton, 2002, p. 303). Being in the context of the study also helped the researchers to "understand how events, actions, and meanings are shaped by the unique circumstances in which these occur" (Maxwell, 1996, p. 19). Furthermore, this contributed to solving design problems in context.

At every stage of the research, the lead researcher acquired help and feedback the other two researchers and two outside experts on the content, method, and procedures of the study. To increase the trustworthiness of the research, the lead researcher kept a diary on the design process, in which she reflected on her experiences and personal insights to draw her attention to the research context. This was very helpful for "discerning patterns of the work in progress, [and] reflecting on previous reflections" (Van Manen, 1990, p. 73).
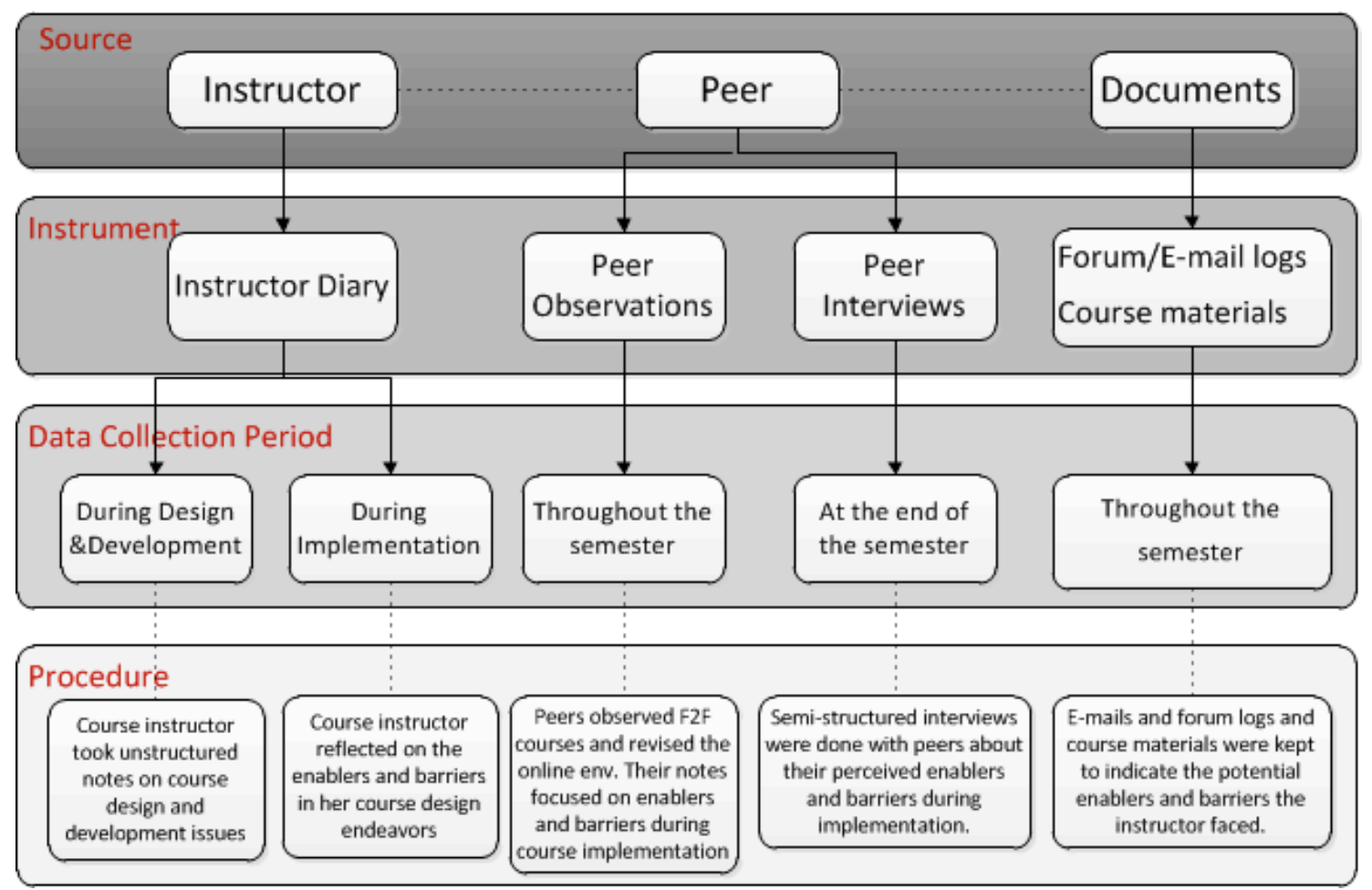

Figure 1. Data collection procedures with related sources. 


\section{The course context}

To conduct the research, an introductory undergraduate course that was previously offered in a F2F format in an in an educational technology program of a school of teacher education at a large university was re-designed for a blended format. This 3-credit course is offered to sophomores in Fall semesters. The content includes the historical background and development of Computer Aided Instruction (CAI), current formats and the status of CAI, and the instructional design process for creating a CAI project. A total of 40 students registered for the thirteen-week course in Spring 2007. The course schedule is shown in Table 1.

Table 1

Course schedule

\begin{tabular}{|c|c|c|}
\hline Week & In-Class & Online \\
\hline 1 & $\begin{array}{l}\text { First Meeting: (Issues of blended format, } \\
\text { introduction to online environment) } \\
\text { CAI: Overview \& Historical Perspective }\end{array}$ & * Links to review \\
\hline 2 & $\begin{array}{l}\text { Applications of CAI - I: Drills - Tutorials } \\
\text { Assignment: Research Paper (1) }\end{array}$ & * Forum: Discussion Topic: Scenario 1 \\
\hline 3 & No class (National Holiday) & * Readings on the e-sources! \\
\hline 4 & $\begin{array}{l}\text { Applications of CAI - II: Simulations - Games } \\
\text { - Problem Solving - WBL } \\
\text { Assignment : Research Paper (2) }\end{array}$ & $\begin{array}{l}\text { * Forum: Discussion Topic: "I think..." } \\
\text { Reflections for a sample WBL environment } \\
\text { * Links to review \& Readings }\end{array}$ \\
\hline 5 & $\begin{array}{l}\text { Basics of Instructional Design for CAI - I } \\
\text { Assignment: Project Paper } 1 \& \text { Research } \\
\text { Paper(3) }\end{array}$ & $\begin{array}{l}\text { * Forum: Discussion Topic: Scenario } 2 \\
\text { * Links to review \& Readings }\end{array}$ \\
\hline 6 & Guest speaker -Discussion Session 1 & $\begin{array}{l}\text { * Forum: Discussion Topic: Reflections } \\
\text { on the Discussion held } \\
\text { * Links to review \& Readings }\end{array}$ \\
\hline 7 & $\begin{array}{l}\text { Guest speaker -Discussion Session } 2 \\
\text { Assignment: Project Paper } 2\end{array}$ & $\begin{array}{l}\text { * Forum: Discussion Topic (cont'd) } \\
\text { * Readings }\end{array}$ \\
\hline 8 & $\begin{array}{l}\text { Basics of Instructional Design for CAI - II } \\
\text { (Students are assigned to sample CAI programs } \\
\text { to evaluate and present on Week 11) }\end{array}$ & $\begin{array}{l}\text { * Forum: Discussion Topic: Reflections } \\
\text { on the Discussion held } \\
\text { * Readings }\end{array}$ \\
\hline 9 & Learning Strategies \& Techniques for CAI & *Forum: Discussion Topic: Final concerns \\
\hline 10 & Student Presentations of Projects (initial) & on topics assigned \\
\hline 11 & Student Presentations for Software Evaluations & * Links to review \\
\hline 12 & Issues on Documentation \& Course Summary & * Readings \\
\hline 13 & Student Presentations of Projects (final) & No activities online! \\
\hline
\end{tabular}

In the previous F2F format, the course was offered as lectures in which the students and the instructor met three hours a week; the course also included assignments and a group project submission. A needs analysis on the course delivery revealed that the students needed an active and engaging learning environment that can support their learning via rich interactions, with adequate feedback and guidance, and collaboration with their peers. The F2F course instructor also needed a flexible learning environment for materials distribution, diverse assignments, discussions, coordination under her/his facilitation, and easier tracking of students' progress with a large class size. Improved interaction and engagement were other needs. After studying the results of this needs analysis, the course was redesigned with a blended format. The components are shown in Table 2. 
Table 2

Components of the blended course

\begin{tabular}{cc}
\hline Proportions & Components \\
\hline & Reading materials, resources \\
Online Components $(50 \%)$ & Forum discussions \\
& Sample links \\
F2F Components $(50 \%)$ & Traditional lectures \\
& Group Work (cooperative learning tasks) \\
& Group discussions \\
\hline
\end{tabular}

During the design of the course, the course instructor designed various activities that incorporated authentic principles and first principles of instruction (i.e., problem, activation, demonstration, application, and integration). Figure 2 displays these themes with their related design issues.

The blended course was designed based on Merrill's First Principles of Instruction (Merrill, 2002; Merrill, Barclay, \& van Schaak, 2008), and included authentic activities, as suggested by Reeves, Herrington, and Oliver (2002). A brief list of the principles and activities follows:

Principle 1: Problem. The instructor designed a term assignment in which the students were supposed to create a real-world CAI project in teams. For this assignment, teams were required to consult K-12 teachers and prepare a CAI project in accordance with their needs. The teams selected a topic of their interest, then went through needs analysis, design and development periods. For several groups the opportunity to implement their CAI products in real settings and evaluate them was enabled. But for the rest, teacher evaluations or small group evaluations were made. The students could discuss their projects in course website that enabled a group discussion area. They were also required to showcase their projects during the development process in class. Other than the project, the students were also required to work on design problems for sample CAI software that was given by the instructor and to discuss real-world scenarios on sample course content in the online forum environment.

Principle 2: Activation. The instructor sought to activate the students' prior knowledge via questions, student elaborations and discussions. Apart from F2F discussions on course content, the students discussed real-world scenarios written by the instructor in the online forum environment. Experts from different companies and from academia were invited to speak in the F2F course to share their experiences, so the students could see the relevance of their knowledge. An online posting area was created for the students to reflect on how they felt and what they thought about the expert seminars. The instructor also created quizzes on previous week's topics to activate prior knowledge and motivate the students for the next session.

Principle 3: Demonstration. To supplement the students' learning, the instructor used online links and esources. The instructor also gathered sample projects from various companies for demonstration in the F2F hours. During the demonstrations, the instructor sought to challenge the students to reflect on the problematic issues, or on important concerns.

Principle 4: Application. The instructor enhanced both instructor feedback, and also the feedback from peers, course assistants, and other TAs in the department via initial presentations in the middle of the project period. The students were encouraged to contact K-12 teachers for the problem section of their projects and to develop CAI material for their classes. For several groups the teachers provided feedback for their final products, and for the other groups, small groups of K-12 students offered feedback.

Principle 5: Integration. The students were asked to report on what they were doing during their project development, with emphasis on how they were integrating what they had learned within their project. Another approach was to ask the students to reflect on sample CAI projects and then present their ideas as a group to the class. Most of the assignments were done in groups, since these kinds of projects are always completed with a team effort in real life. In addition, the students were supposed to use their projects in schools as real life applications and then evaluate their projects. 


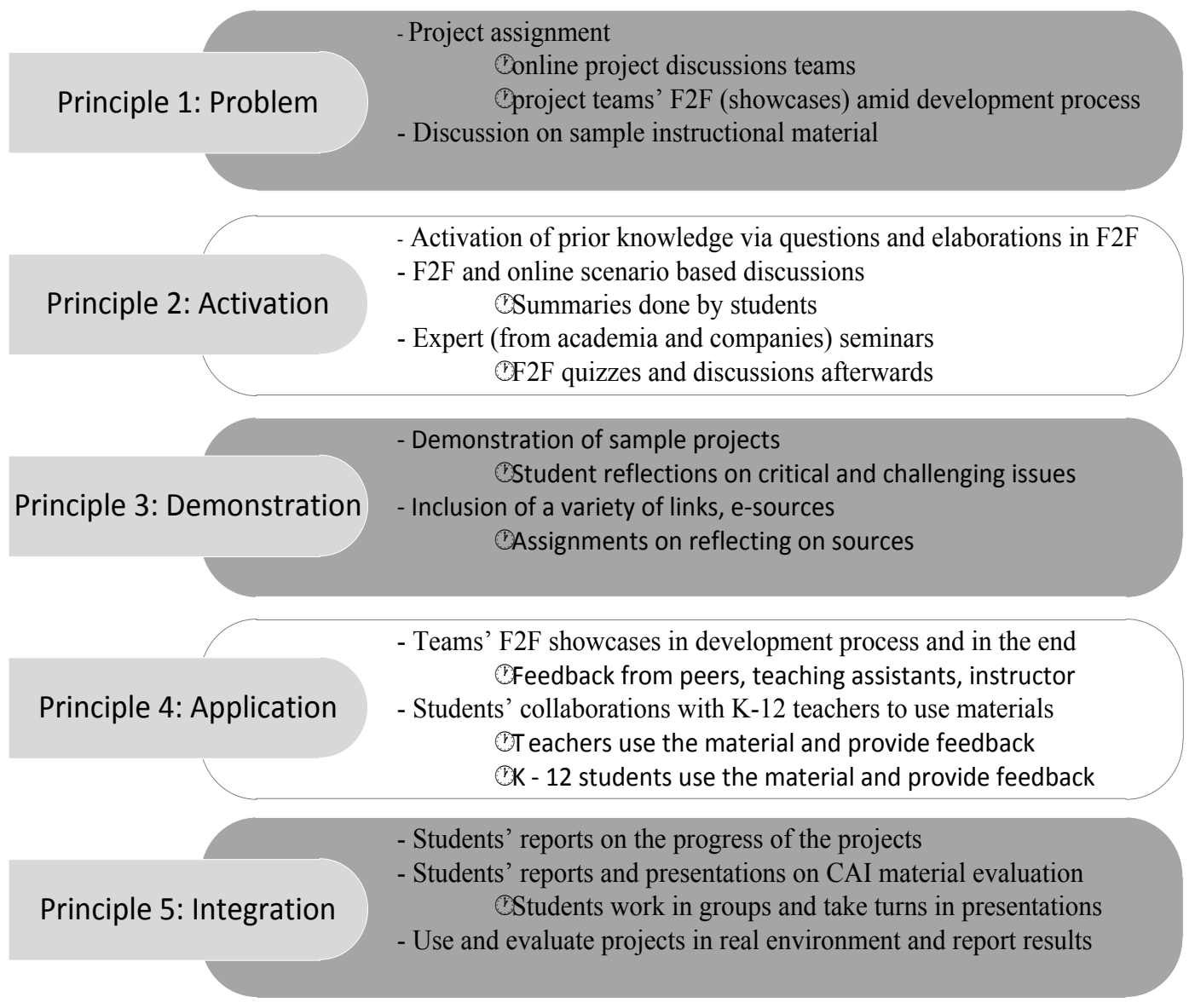

Figure 2. Uses of Merrill's Principles of Instruction in the design decisions.

\section{The course website}

In designing the online component of the blended course, a learning management system (LMS) developed by departmental staff was used. The course assistants and the instructor used the instructor mode to upload and manage documents, and to track student involvement. The main categories of the LMS included a general menu on the left side, ordered with text-buttons; an icon-based menu with communication and collaboration tools; and a layout on the rest of the page for the presentation of the content. The left-frame menu included the items: introduction, objectives, syllabus, lecture, grading, homework, links, e-sources, news, instructor, and frequently-asked question items. Figure 3 shows the objectives page. 


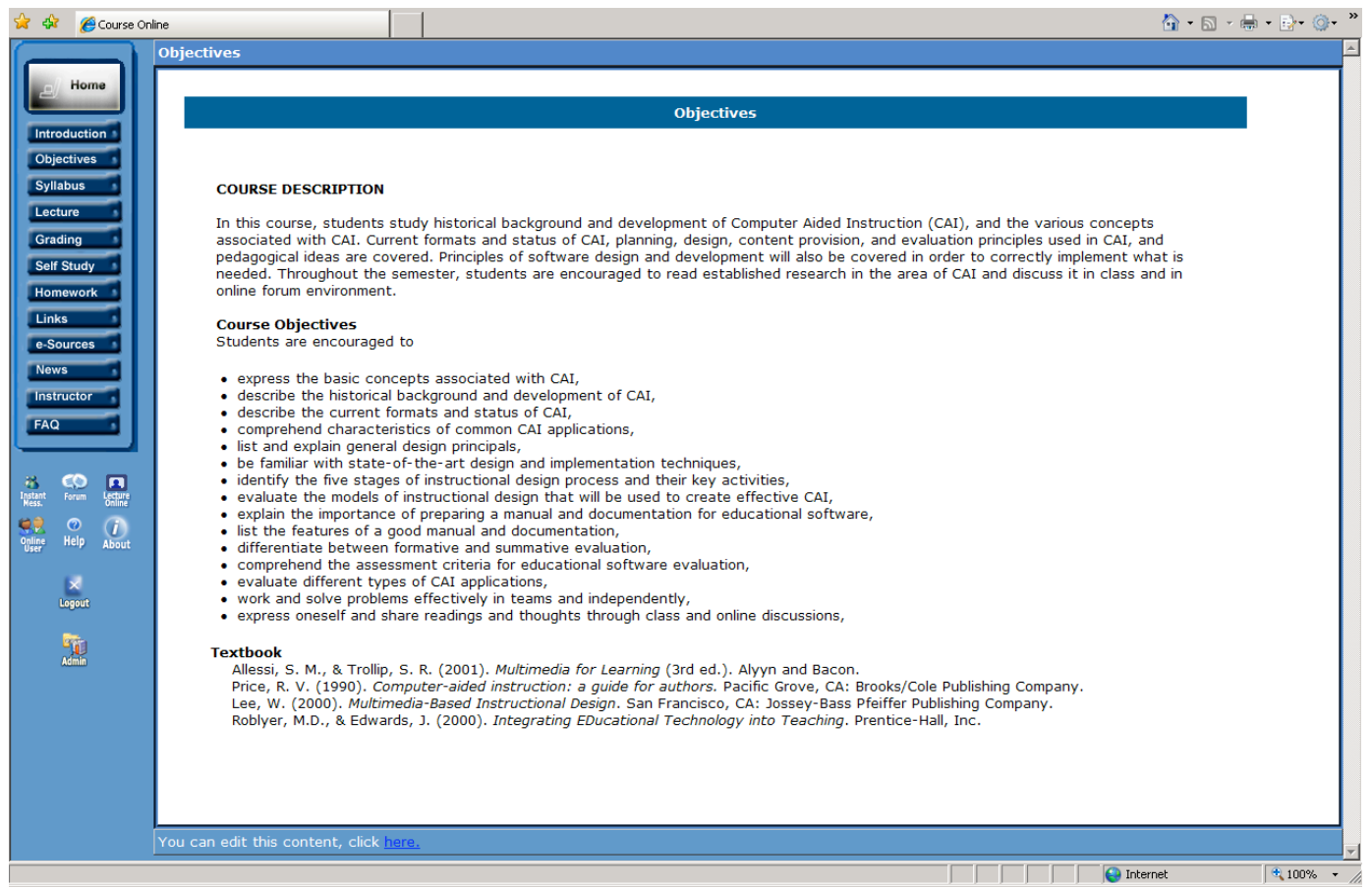

Figure 3. Objectives page of the online environment.

The interface that the instructor used to manage the site is provided in Figure 4. The peer who used the LMS before and the instructor were in contact with the developers of the LMS to fix problems they experienced.

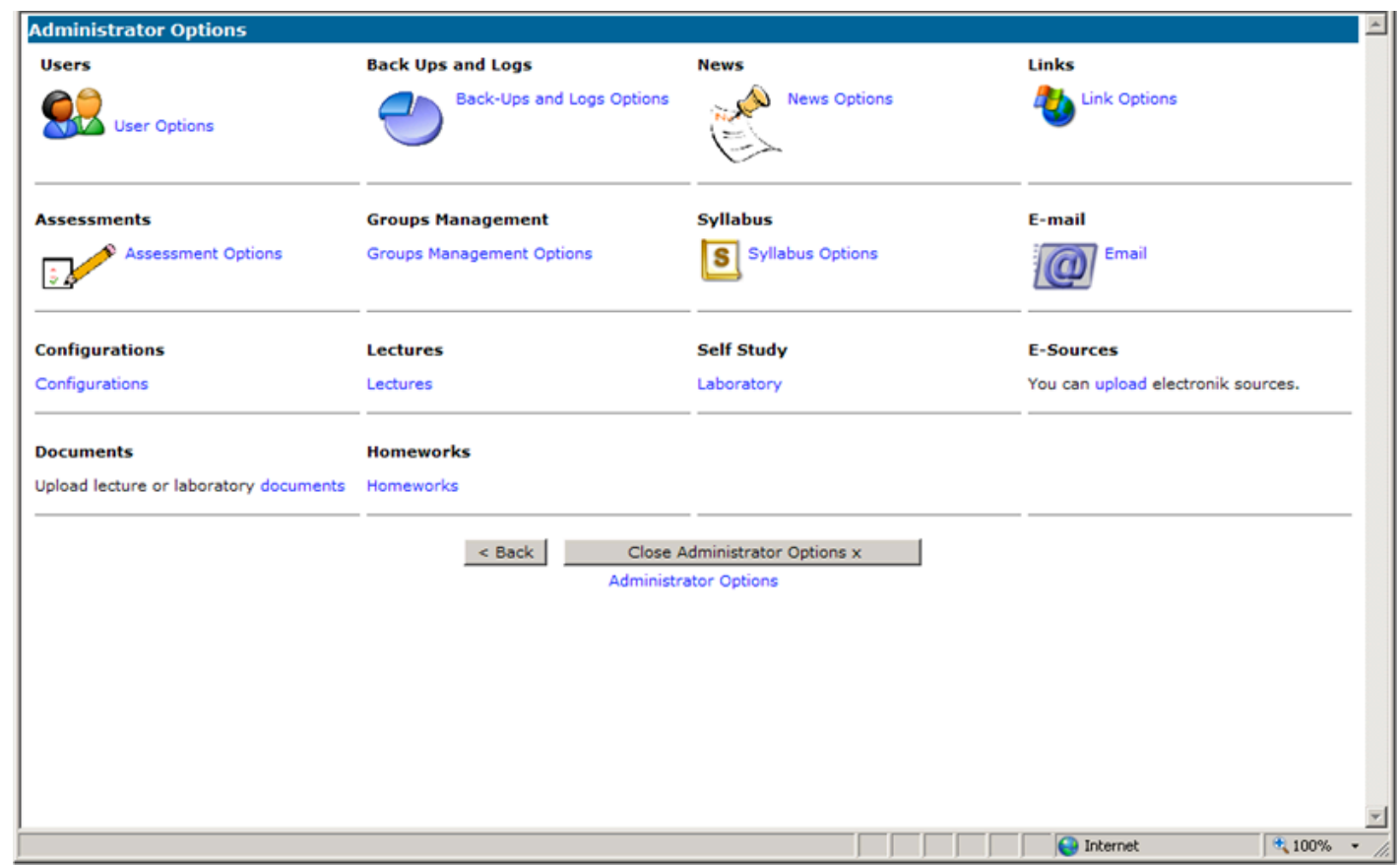

Figure 4. Administrator page for the course instructor. 


\section{Results and discussion}

The findings and related discussion are presented in this section, and are based on each research question. Initially, the results of the design considerations analysis are presented. Then, the results regarding the affordances for the use of the BLE during implementation are presented. Finally, the results regarding the challenges during the implementation are presented.

\section{Design considerations in the blended course}

Considerations regarding the pedagogical approach

The course instructor needed to integrate a design framework that not only would facilitate the F2F or online environment individually, but would enable the harmony of both. For this need, the instructor decided to make use of the First Principles of Instruction (Merrill, 2002; Merrill \& Wilson, 2007) to create a learner-centred and authentic learning environment (Reeves, Herrington, \& Oliver, 2002). In her notes, the instructor wrote:

... I want my students to be very active throughout [the entire], semester as this is my core pedagogical concern. ... Since this is the core of my pedagogical approach, I will apply the First Principles of Instruction, which I believe fit the needs of the course content within this context... I can use authentic tasks for my activities to make them more meaningful for the students and hence motivating.

Pedagogy is a major component for any learning environment, since it offers a foundation for its design, and provides instructional guidelines needed for effective and efficient teaching (Bednar, Cunningham, Duffy, \& Perry, 1992). In this case, the instructor's efforts to improve the pedagogical approaches of the F2F environment for the BLE can point the importance of establishing an improved pedagogy to support the move from one delivery environment to another. The design and development considerations for the new learning environment, therefore, can be considered dependent on the pedagogical principles that shape the new/improved pedagogy.

The findings show that using Merrill's Principles of Instruction provided the instructor with a facilitative approach, since the principles "relate to creating learning environments and products rather than prescribing how learners acquire knowledge and skills from these environments or products" (Merrill, 2002 , p. 44). It also provided the instructor with a clear and concise conception of the students' and the instructor's roles, and with a clarification of the context (Ertmer \& Newby, 1993; Koohang \& Durante, 2003).

Considerations regarding the course organization and materials preparation

The data analysis revealed considerations about balancing the F2F and the online portions of the course, gathering the F2F and online materials, uploading and organizing the online documents, and preparing the F2F course documents. In her notes three weeks ahead of semester, the instructor wrote:

... I identified new resources to improve my PPT [PowerPoint] slides and my electronic sources... I needed to include many more links and examples online... It is really hard to balance the course activities in the F2F and online environments. I don't exactly know how to set an agenda for where each activity would fit. So, it takes time to arrange them all appropriately to fit my pedagogical concern...

The results indicate issues that require careful attention during the course organization phase, especially when translating F2F sources to the online environment and when creating online materials. The online environment can serve as a place where F2F documents are stored for students' easy access (Olapiriyakul $\&$ Scher, 2006), as well as a place for providing particular online documents.

During the F2F course organization, the instructor considered introducing the content first, with elaboration and group discussions. In the online environment, the students were to study the content further via links and e-sources, and were asked to reflect on the forum discussions individually and within groups. Therefore, the sequence was F2F first, online second -- although the two portions were designed to be equal. In order to decrease the potential technical challenges that the students might face, another 
consideration was to design an orientation session. The instructor noted: "I finished writing the rules for how to write in forum discussions. I can revise them in the orientation session with the students, to reach a mutual agreement on the rules. But I know for sure that they need to be reminded of them."

Considerations regarding interaction and roles

Interaction is valued as a key ingredient in learning environments (Wagner, 1994; Woo \& Reeves, 2007). Considering the asynchronous capabilities of the online environment, the literature reports that improved interaction is regarded as one of the most important needs when shifting to a BLE, due to advances in communication technologies (Garrison \& Vaughan, 2008; Palloff \& Pratt, 2007). In this study, the instructor tried to enrich of all of the types of interaction that could be considered critical in BLE designs. Regarding student-student interactions, the following concerns were noted:

... I will involve the students in group tasks, in which they will discuss the issues that I will assign to them. ... Online discussions will help them to interact with each other after the course content portion of the F2F session ends. When the projects begin, I will create a thread in the forum for each group, so they can continue their interaction online $7 / 24 \ldots$.

For instructor-student interactions, the instructor considered F2F interaction via question-answer and discussion sessions. In the online sessions, their interactions comprised a smaller component than in the F2F sessions. The forum environment was the only place online where the students could actively interact with the content and their peers.

The instructor's (or designer's) role is said to be critical to the success of BLEs (Rowley, Bunker, \& Cole, 2002). The instructor's notes on the strategies in this study show that the she aimed to make the students active participants, and she intended to play a role in facilitating discussions, arranging course activities, coordinating group work, etc. The instructor also played a dominant role in providing information, due to the introductory nature of the course.

The students played both active and passive roles. The activities showed that the students were active in group work, in online and F2F discussions, and in the project development process. But they were mostly passive in the information gathering processes. With a large class size, the encouragement of student participation can be easier, thanks to the online components of the BLE (Garrison \& Vaughan, 2008; McCray, 2000). BL offers a diverse set of opportunities for expanding the students' and the instructor's roles; and in this study, these opportunities can be considered to have further extended for a large class size in which it is very hard to make all students active.

\section{Affordances for the use of the BLE during the course implementation}

The major categories of affordances were arousal of the students' interest and participation; flexibility; time conservation in course activities; easy tracking of student progress; and the provision of interaction, collaboration, and communication opportunities. Similar affordances were reported in related research; these included improved pedagogy (Aycock, Garnham, \& Kaleta, 2002; Dziuban, Hartman, \& Moskel, 2004; Voos, 2003), flexibility (Graham, 2006; Palloff \& Pratt, 2007; Rovai \& Jordan, 2004), and increased collaboration, communication, and interaction opportunities (Bonk, Kim, \& Zeng, 2006; Littlejohn \& Pegler, 2007; Osguthorpe \& Graham, 2003).

The results reveal that the use of the BLE helped the instructor to attract maximum attention from the students and increased the students' participation. In Week 8, the instructor wrote the following note:

... I asked questions about the subject to make them attend the course. ... They seemed interested. But there are still some particular students who have not been talking or saying anything from the beginning of the semester. ... In fact, they are more active in the online environment. I am happy to see that everyone can participate in some way...

Peer C also offered her perceptions:

First of all, the instructor was able to attract maximum student attention [thanks to the $\mathrm{BLE}$. It is a major plus that students can contact their instructor both in the F2F and the 
online environments. ... I think almost all of the students had a chance to participate, considering the whole course structure.

Flexibility in moving from one environment to another was another affordance. The instructor was pleased to manage time and the course requirements flexibly in the different environments: "...Time efficiency was a problem for me this week. ... Since I could not cover all of the content, I told the students that they could look at the website and documents I prepared for them online and ask questions anytime. Good to manage things in somehow!"

In an observation note from Week 9, Peer A noted that timing was limited for the guest seminar session, and the instructor announced that the students should post their questions in the forum. Peer B explained his ideas on this issue:

The invited guests came to the F2F sessions and explained things. Discussions were held afterwards, but having extended discussions on new ideas [regarding] the content or linking the issues with the course content in the online environment enabled these discussions [to be undertaken] in written format. That is, they could be extended and were recorded. ...

Moving from one environment to another when needed is greatly appreciated by course instructors (Palloff \& Pratt, 2007), due to time savings and more flexible management of the course requirements (Dziuban et al., 2004; Graham, 2006; Palloff \& Pratt, 2007; Rovai \& Jordan, 2004, So \& Bonk, 2010). Regarding the saving of time for certain course activities, Peer B stated:

... In the F2F course, the instructor already uses two hours to present the theoretical information, [providing] examples and making the students work in groups and small discussions. In order to discuss more issues regarding the content, she needed extra F2F hours, which cannot be convenient in a thirteen-week course. Moving these discussions to the online environment saved time for the instructor. ....It also helped the in-class activities and lectures to go smoothly and efficiently.

It was also easier for the course instructor to keep track of the students' progress. Peer C said: "I think it was easier for the instructor to see how the students were doing. Students who did not come to class could participate every time online." Therefore, the instructor had more interaction opportunities to see how students were doing. Peer A also pointed out the role of the online environment: "The words are flying but postings are staying there [to help evaluate students better]." That is, the instructor could more objectively evaluate student participation in a BLE. Peer $\mathrm{C}$ also mentioned interaction and communication opportunities: "Using both environments enriched student-instructor and student-student interaction, which was great for the instructor to increase the quality of a very demanding course."

There are also several other suggested main affordances for the use of BL in the literature, but they were not found to be critical in the scope of this study. These included increased cost-effectiveness (Chamberlain, Davis, \& Kumar, 2005; Koohang \& Durante, 2003), improved retention (Heterick \& Twigg, 2003), and improved outcomes (Boyle, Bradley, Chalk, Jones, \& Pickard, 2003; Garnham \& Kaleta, 2002; McCray, 2000). Cost-effectiveness was not a significant affordance in this study, because the features of the course context were already available. Improved outcomes and improved retention may not have been important because the focus of the researcher was more on the process than on the product. These results might suggest that the intent and focus of the instructor or instructional designer (IDer) of a BLE can determine its enabling features.

\section{Challenges to the use of the BLE during the course implementation}

The challenges were difficulties in course management, workload, overlaps, and creating harmony between the two environments. The literature records both similar and diverse challenges to the use of BLEs in other studies. The commonly found issues were increased time devotion (Dziuban et al., 2004), increased workload (Bates \& Poole, 2003; Lefoe, Gunn, \& Hedberg, 2006; Littlejohn \& Pegler, 2007; Owston, Garrison, \& Cook, 2006), and deciding on the right blend (Rowley et al., 2002) -- all regardless of the institutional level (i.e., k-12, corporate, higher education). 
The difficulties regarding course management are related to the design of the activity portions in the F2F and online environments. Peer B mentioned this decision challenge: "To give announcements in class or online, to cover a topic in class or online seemed to be great challenges. ...Timing and managing the tasks in these environments were difficult for the instructor." One of the most important management issues was time management. It was very challenging to decide how much time to spend in online and F2F discussions, or giving feedback, or managing student complaints and requests. Peer A reported that it might be very difficult for the instructor to arrange time to respond to the students' posts, because there were a lot of responses. Peer $\mathrm{C}$ stated this concern: "The instructor needed to manage both the online and the F2F environments by controlling the environment. She needs to provide feedback all the time, answer their questions, etc." Providing appropriate feedback was also mentioned as a challenge for an instructor in the literature on online environments (e.g., Lin \& Lehman, 1999). The instructor needs to be flexible in the online environment while managing the time and the course (Eastmond, 2000; Hiltz \& Goldman, 2005; Hoffman, 2006; Palloff \& Pratt, 2007).

The second challenge was increased workload. In Week 8, the instructor wrote: "It took a lot of time again to upload documents and links to the webpage. ...For the online presentation, I spend at least 5 hours to record my voice, and to synchronize this with the PPT slides. " Peer A also stated a concern: "The instructor begins with a greatly busy schedule. ...Secondly, it [BLE] is tiring for the instructor cognitively as well as physically. ... Whenever students ask in-depth questions in class or online, she needs to provide immediate answers." Compared to a F2F course, regular preparation time was doubled in the online environment. There, the instructor needed to deal with students' posts and the technical maintenance of the system, as well as with the uploading of documents and forum posts. Supporting this result, it was suggested in the literature that instructors should not be the "webmaster" (Bates \& Poole, 2003, p. 187). Instead, they might obtain help from teaching assistants (Garrison \& Kanuka, 2004), or a technical support team at his/her institution. Still, using an online system may require considerable time for instructors (Johnson et al., 2011).

The results show that the BLE placed a burden on the instructor not only physically (i.e., taking up her time), but also cognitively. This finding contradicts Garrison and Vaughan's (2008) argument. They argued that, if designed carefully, BLEs can ease the workload. Although designed with a lot of consideration regarding her needs, the instructor could not avoid increased workload. Lack of experience can be regarded as a reason for such a challenge (Voos, 2003), which implies a considerable concern for novice instructors or IDers.

Peer A argued that overlaps in the online and F2F environments were a great challenge: "...Activities can support or inform each other, but should not repeat each other. This sometimes happened in the course in terms of discussions." This result indicates that while repeating can benefit students' learning, it might create a challenge to balance the learning environment in terms of time and course management. The course instructor reported her concern:

Sometimes, it was hard for me to summarize and rephrase student responses to my questions. I tried to provide positive reinforcement every time. But this week I felt stuck in the similar discussion we had in the ID discussion [the latest online discussion]. Some are making it harder for me to create a balance. (Week 8)

The final challenge was creating harmony between the two environments in terms of time, function, and relevancy of activities. These are all related to design considerations which affect the implementation of the course, as Peer A noted: "The instructor tried to avoid overlaps: which one is better for either F2F or online. She tried to elicit students' ideas about how to rectify this difficulty... One final grade for all the different tasks: it must be very hard." Deciding on how to grade, and how much of the online and F2F activities to assess, was another challenge for the novice instructor. The instructor's diary reflected this challenge: "I tried to figure out my evaluation chart once again, and it is really hard to balance the participation for online and F2F hours. I have difficulty in grading them" (Week 13). This issue can be attributed to instructor competencies as well as previous experience. 


\section{Implications and Conclusion}

The meaning of learning does not change with new technologies and methods, but delivery mechanisms may take new forms (Klein, Spector, Grabowski, \& de la Teja, 2004). In designing a BLE, many considerations must be undertaken by the course designer. What makes these considerations different from traditional F2F or online courses are the issues of a joint environment discussed previously. A study by Ellis, Steed, and Applebee (2006) showed that instructors conceptualize BL very differently during implementation. While some conceived it as a support for student learning, others found it to be mostly a technological media. The results of the current study suggest that the joint use of two environments entailed a new design approach that requires harmonization of the environments not only in terms of the media and technologies used, but also regarding design approaches. It can also be argued that the use of Merrill's First Principles of Instruction and authentic learning as a dual framework for the design suited the needs of the BLE in this study. This allowed the use of an evolved pedagogy with a focus on the problem-based nature of learning, enrichment of learning with authentic activities, and the prescriptions identified for ID. The results show that the use of the "problem" theme was helpful both as an introduction to the foundational content, and for the other application issues (i.e., educational software including drill-practice, tutorials, games, etc.). In addition, as Reeves et al. (2002) mentioned, predicting the challenges that might arise from the design of these activities beforehand is not easy. However, it can be argued that these main themes helped the instructor to frame the activities more easily. It also allowed the instructor to form a clear and concise conception of the students' and the instructor's roles, and it helped to clarify the context.

The joint use of the online and F2F environments in this study enabled the course instructor to arouse student interest, to manage time and course activities flexibly; to save time for course activities; to track student progress easily; and to engage in extensive interaction, collaboration, and communication with students. However, the instructor struggled with course management, workload, overlaps, and creating harmony between the two environments. As Collins et al. (2004) proposed, the implementation period of a design requires considerations that go beyond the actual design. This suggests the importance of iterations and instant modifications, which are consistent with the needs of the learning environment. Iterations are parts of the design process in all phases (Dick, Carey, \& Carey, 2001; Posner \& Rudnitsky, 2001). In this study, they were critical in the course design process. Another main conclusion from the findings of this study is that an evolved pedagogy for the design of the BLE was the most important issue; but the institutional issues, such as support and technical aspects, also played critical roles. Based on these results, the design issues that were critical to the use of the BLE can be identified as context, pedagogical issues, instructor competency, and technical issues (Figure 5).

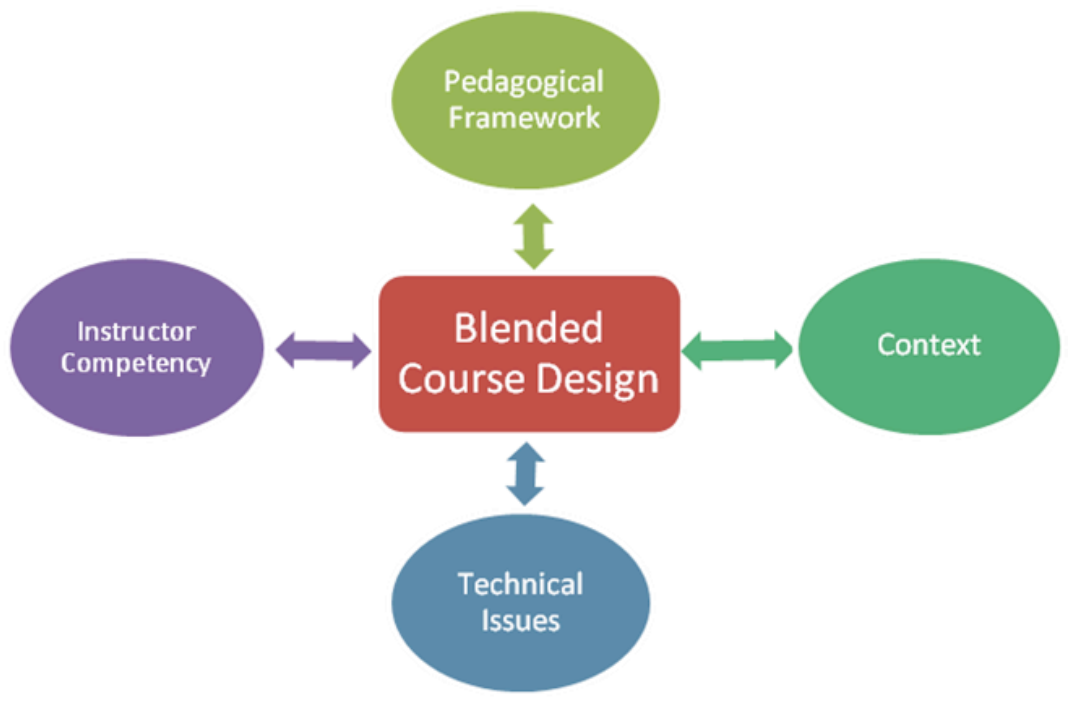

Figure 5. Critical issues in the blended course design. 
Regarding the context of the course, two sets of issues can be identified as critical: curricular and institutional issues. They are important for developing a rationale for the design of the learning environment (Posner \& Rudnitsky, 2001; Tyler, 1949). The nature of the course played a big role in determining the strategies and hence the design of the blended course. Institutional and administrative issues were also critical to the design of the course, since support from the institution is critical to the creation and maintenance of both the online and the F2F environments. Support concerning logistics, including technical support and management of the learning environment, was critically needed. Therefore, an analysis of the institutional deliverables and support mechanisms should be made before designing a blended course.

It is also important to note that the blended delivery format was a conversion from a traditional format, not a new creation from scratch. There two major aspects of this issue for the course design decisions. First, the major issue was the availability of content and materials; in this case, the instructor had already decided upon the curriculum and content, which shortened the time needed for the development of materials and content (Bates \& Poole, 2003). Regarding this issue, Boyle et al. (2003) suggested a smooth and unrushed transition between the familiar issues and new issues involved. Based on the study results, making resources available in multiple formats to be used in both the online and F2F environments is recommended. However, it should be noted that the assumption that adapting existing formats to create a blended format would be an easy process can be wrong. As Hofmann (2006) argued, it is easier to start from scratch than to redesign an existing program. This is because of required shifts in fundamental concepts while re-designing. This argument parallels Garrison and Kanuka's (2004) BL definition: "Blended learning inherently is about rethinking and redesigning the teaching and learning relationship" (p. 5). The results of the study support this idea: although the instructor made use of the resources of previous F2F course, she needed to rethink and redesign all of the course dynamics. Therefore, the second critical issue can be considered as the importance of being consistent in using the planned functions of each environment of the BLE when starting with an existing course.

The pedagogical approach was critical to the course design. This determines and specifies of the instructional approaches and strategies to be used, influences the instructor's and students' roles, and also influences motivation, interaction, communication, and cooperation in the course (Ertmer \& Newby, 1993). Therefore, deciding on the best pedagogical approach to meet the specific needs of the blended course is the first crucial step. Another concern was the creation of harmony between the online and F2F environments in terms of enriched interaction, intensive communication, and cooperation among all of the parties. It can be argued that the pedagogical framework needs to support IDers or instructors by offering sound evidence that can serve as a guide while designing harmony and richness into the course activities for the purpose of enhancing communication, collaboration, interaction, and technical aspects. In this study, the instructional aims, scope, and course objectives suggested an approach that matched the use of Merrill's Principles of Instruction. In addition, the use of authentic activities integrated well with Merrill's Principles of Instruction, and was very helpful for enriching the interaction and for creating meaning. The use of these two frameworks is highly recommended for future blended courses. Regarding the course implementation, it is also recommended that the use and functions of the BLE should be communicated to the students beforehand. Their responses should additionally first be taken into account.

Instructor competency is regarded as a fundamental issue for the success of any learning environment. For BLEs, instructor competency is related to the competencies specific to both the F2F and the online environments, as every environment demands different instructor roles (Klein et al., 2004). The current study results suggest that the required competencies to use a BLE effectively encompass those needed for both of these formats. The instructor needed to be knowledgeable concerning content, competent in technology use, and proficient in managing the online environment, while managing time and the classroom. It can be argued that the importance of the instructor's role increases in a BLE in terms of creating balance. Another aspect is the experience that is needed for instructors to develop necessary competencies. The instructor's possession of experience in online teaching and technology use has already been suggested as a basic foundation for successful implementation (Olapiriyakul \& Scher, 2006). This implies the importance of experience as a critical part of teaching. As was suggested by So and Bonk (2010), training in learning and teaching with BLEs are required for novice instructors. Working and collaborating with colleagues while offering blended courses is also recommended. In addition to instructor competencies in using software tools, student competencies and literacy may also need to be considered to create a successful design (Johnson et al., 2011). 
Finally, the technical issues for the design of the BLE were mostly related to the needs of the online environment. The technical availability, usability, and maintenance of the online environment were critical to the use of the BLE during all stages of the design process and implementation. Experience with the system (Woods, Baker, \& Hopper, 2004) should be considered critical, as well as knowing the functions of the LMS components. The present study also shows that instructors must be provided with necessary deliverables for the online and F2F environments, as well as with technical support for the maintenance of the online system.

\section{Limitations and Suggestions for future research}

This study involved an investigation of a BLE over a 13-week course in a foundational, educational technology course. Given the design-based nature of the study, it is hard to generalize the findings for other settings, since "the effectiveness of a design is no guarantee of its effectiveness in other settings" (Collins et al., 2004, p. 18). However it is hoped that the contextualized nature of the DBR can yield guidelines for similar design contexts or even contribute to broader contexts (Gravemeijer \& Cobb, 2006). Further, the lead researcher of this study was also a participant as an instructor. Although this limitation was offset by eliciting peer reviews and expert opinions during all of the processes, the researcher effect cannot be excluded from the study. It should also be noted that the design processes were limited to analysis, design and development, and implementation processes, but the evaluation process was excluded. Future research might be focused on formative and summative evaluation processes of a BLE. This study shows that Merrill's Principles of Instruction contributed to the framework of the course design. Additional research can be conducted to investigate the students' perceptions of these principles' effects during their course implementation. An investigation into the effects of other pedagogical approaches and ID models could also be a subject of further study. Future research can additionally focus more on design issues for BLEs that use different media and technologies. Finally, within the scope of the course design in this study, a local LMS was used. Certain features of this environment might have affected the experiences and perceptions of the participants. An investigation of the different uses of LMSs and/or different online learning environments therefore might also be useful.

\section{References}

Allen, I. E., Seaman, J., \& Garrett, R. (2007). Blending in: The extent and promise of blended learning education in the United States. Retrieved from http://www.sloanc.org/publications/survey/pdf/Blending_In.pdf

Aycock, A., Garnham, C., \& Kaleta, R. (2002). Lessons learned from the hybrid course project. Teaching with Technology Today, 8(6). Retrieved from http://www.uwsa.edu/ttt/articles/garnham2.htm.

Bates, A. W., \& Poole, G. (2003). Effective teaching with technology in higher education: Foundations for success. San Francisco: Jossey-Bass.

Bednar, A. K., Cunningham, D., Duffy, T. M., \& Perry, J. D. (1992). Theory into practice: How do we link? In T. M. Duffy, \& D. H. Jonassen (Eds.), Constructivism and the Technology of Instruction: A Conversation (pp. 17-34). New Jersey: Lawrance Erlbaum.

Bliuc, A., Goodyear, P., \& Ellis, R. A. (2007). Research focus and methodological choices in studies into students' experiences of blended learning in higher education. Internet and Higher Education, 10, 231-244.

Bonk, C. J., Kim, K. J., \& Zeng, T. (2006). Future directions of blended learning in higher education and workplace learning settings. In C. J. Bonk \& C. R. Graham (Eds.), Handbook of blended learning: Global perspectives, local designs (pp. 550-567). San Francisco: Pfeiffer Publishing.

Boyle, T., Bradley, C., Chalk, P., Jones, R., \& Pickard, P. (2003). Using blended learning to improve student success rates in learning to program. Learning, Media and Technology, 28(2), 165-178.

Brown, J. S., Collins, A., Duguid, P. (1989). Situated cognition and the culture of learning. Educational Researcher, 18(1), 32-42.

Chamberlain, M., Davis, L., \& Kumar, M. (2005). The University of Houston embraces hybrid instruction. Texas Journal of Distance Learning, 2(1), 17-23. 
Collins, A., Joseph, D., \& Bielaczyc, K. (2004). Design research: Theoretical and methodological issues. Journal of the Learning Sciences, 13(1), 15-42.

Design-Based Research Collective. (2003). Design-based research: An emerging paradigm for educational inquiry. Educational Researcher, 32(1), 5-8.

Dick, W., Carey, L., \& Carey, J. O. (2001). The systematic design of instruction (5th ed.). New York: Longman.

Douglass, B. G., \& Moustakas, C. (1985). Heuristic inquiry: The internal search to know. Journal of Humanistic Psychology, 25(3), 39-54.

Dziuban, C., Hartman, J., \& Moskal, P. (2004). Blended learning. ECAR Research Bulletin. Retrieved from http:/www.educause.edu/ir/library/pdf/ERB0407.pdf

Eastmond, D. (2000). Enabling student accomplishment online: An overview of factors for success in web-based distance education. Journal of Educational Computing Research, 23(4), 343-358.

Ellis, R. A., Steed, A. F., \& Applebee, A. C. (2006). Teacher conceptions of blended learning, blended teaching and associations with approaches to design. Australasian Journal of Educational Technology, 22(3), 312-335.

Ertmer, P. A., \& Newby, T. J. (1993). Behaviorism, cognitivism, constructivism: Comparing critical features from an instructional design perspective. Performance Improvement Quarterly, 6(4), 50-72.

Garnham, C., \& Kaleta, R. (2002). Introduction to hybrid courses [electronic version]. Teaching with Technology Today, 8(6). Retrieved from http://www.uwsa.edu/ttt/articles/garnham.htm

Garrison, D. R., \& Kanuka, H. (2004). Blended learning: Uncovering its transformative potential in higher education. Internet and Higher Education, 7(2), 95-105.

Garrison, D. R., \& Vaughan, N. D. (2008). Blended learning in higher education: Framework, principles, and guidelines. San Francisco: Jossey-Bass.

Grabinger, S. (1996). Rich environments for active learning. In D. H. Jonassen (Ed.), Handbook of Research for Educational Communications and Technology. New York: Macmillan Library Reference.

Graham, C. R. (2006). Blended learning systems: Definition, current trends, and future directions. In C. J. Bonk \& C. R. Graham (Eds.), Handbook of blended learning: Global perspectives, local designs (pp. 3-21). San Francisco: Pfeiffer Publishing.

Gravemeijer, K., \& Cobb, P. (2006) Design research from a learning design perspective. In J. van den Akker, K. Gravemeijer, S. McKenney, \& N. Nieveen (Eds.), Educational design research (pp. 17-51). London: Routledge

Harris, P., Connolly, J., \& Feeney, L. (2009). Blended learning: Overview and recommendations for successful implementation. Industrial and Commercial Training, 41(3), 155-163.

Herrington, J., \& Oliver, R. (2000). An instructional design framework for authentic learning environments. Educational Technology Research and Development, 48(3), 23-48.

Herrington, J., Reeves, T.C., \& Oliver, R. (2010). A guide to authentic e-learning. London : Routledge.

Herrington, J., Reeves, T.C., Oliver, R., \& Woo, Y. (2004). Designing authentic activities in web-based courses. Journal of Computing in Higher Education, 16(1), 3-29.

Heterick, B., \& Twigg, C. (2003). The learning marketspace. Retrieved from http://www.thencat.org/Newsletters/Feb03.html

Hiltz, S. R. \& Goldman, R. (2005). Learning together online: research on asynchronous learning networks. Mahwah: Lawrence Erlbaum Associates.

Hofmann, J. (2002). Blended learning case study. In A. Rossett (Ed.), The ASTD E-Learning Handbook (pp.516-519). McGraw-Hill. 
Hofmann, J. (2006). Why blended learning hasn't (yet) fulfilled its promises: Answers to those questions that keep you up at night. In C. J. Bonk \& C. R. Graham (Eds.), Handbook of blended learning: Global perspectives, local designs (pp. 27-40). San Francisco: Pfeiffer Publishing.

Johnson, E.M., Cowie, B., De Lange, W., Falloon, G., Hight, G., \& Khoo, E. (2011). Adoption of innovative e-learning support for teaching: A multiple case study at the University of Waikato. Australasian Journal of Educational Technology, 27(3), 499-513

Jonassen, D. (1999). Designing constructivist learning environments. In Ed. C. M. Reigeluth (Ed.) Instructional- Design Theories and Models. (Vol II, pp. 215-239). Lawrence Erlbaum Associates, Publishers, London.

Klein, J.D., Spector, J.M., Grabowski, B., \& de la Teja, I. (2004). Instructor competencies: Standards for face-to-face, online, and blended settings (3rd ed.). Greenwich: Information Age Publishing.

Koohang, A., \& Durante, A. (2003). Learners' perceptions toward the web-based distance learning activities/assignments portion of an undergraduate hybrid instructional model. Journal of Information Technology Education, 2, 105-113.

Lefoe, G., Gunn, C., \& Hedberg, J. (2002). Recommendations for teaching in a distributed learning environment: The students' perspective. Australian journal of Educational Technology, 18(1), 40-56.

Lin, X., \& Lehman, J. D. (1999). Supporting learning of variable control in a computer-based biology environment: Effects of promoting college students to reflect on their own thinking. Journal of Research in Science Teaching, 36(7), 837-858.

Littlejohn, A. H., \& Pegler, C. (2007) Planning for blended learning. London: Routledge.

Marshall, C., \& Rossman, G. B. (1999). Designing qualitative research (3rd ed.). Thousand Oaks: Sage Publications.

Maxwell, J. A. (1996). Qualitative research design: An interactive approach. Thousand Oaks, CA: Sage.

McCray, G. E. (2000). The hybrid course: Merging on-line instruction and the traditional classroom. Information Technology and Management, 1(4), 307-327.

McKenney, S., Nieveen, N., \& van den Akker, J. (2006). Design research from a curriculum perspective. In J. Van den Akker, K. Gravemeijer, S. McKenney, \& N. Nieveen (Eds.), Educational design research (pp. 67-90). New York: Routledge.

Means, B., Toyama, Y., Murphy, R., Bakia, M., \& Jones, K. (2009). Evaluation of evidence-based practices in online learning: A meta-analysis and review of online learning studies. Washington, D.C.: U.S. Department of Education. Retrieved from http://www2.ed.gov/rschstat/eval/tech/evidence-basedpractices/finalreport.pdf].

Merrill, M. D. (2002). First principles of instruction. Educational Technology Research and Development, 50(3), 43-59.

Merrill, M. D. (2007). First principles of instruction: A synthesis. In R. Reiser \& J. Dempsey (Eds.), Trends and Issues in Instructional Design and Technology (2nd ed., pp. 62-71). Upper Saddle River: Pearson.

Merrill, M. D., Barclay, M., \& van Schaak, A. (2008). Prescriptive principles for instructional design. In J. M. Spector, M. D. Merrill, J. Van Merrienboer, and M. P. Driscoll (Eds.), Handbook of Research on Educational Communications and Technology (3rd ed., pp. 173-184). New York: Lawrence Erlbaum Associates.

Merrill, D., \& Wilson, B. (2007). The future of instructional design (point/counterpoint). In R. Reiser \& J. Dempsey (Eds.), Trends and Issues in Instructional Design and Technology (2nd ed., pp. 335-350). Upper Saddle River: Pearson.

Moustakas, C. (1990) Heuristic research: Design, methodology and applications. Newbury Park: Sage Publications.

Olapiriyakul, K., \& Scher, J. M. (2006). A guide to establishing hybrid learning courses: Employing information technology to create a new learning experience, and a case study. Internet and Higher Education, 9, 287-301. 
Oliver, R., Herrington, J., \& Reeves, T. C. (2006). Creating authentic learning environments through blended-learning approaches. In C. J. Bonk \& C. R. Graham (Eds.), Handbook of blended learning: Global perspectives, local designs (pp. 502-515). San Francisco, CA: Pfeiffer Publishing.

Osguthorpe, R. T., \& Graham, C. R. (2003). Blended learning environments: Definitions and directions. Quarterly Review of Distance Education, 4(3), 227-233.

Owston, R. D., Garrison, D.R., \& Cook, K. (2006). Blended learning at Canadian universities: Issues and practices. In C. J. Bonk \& C. R. Graham (Eds.). Handbook of blended learning: Global perspectives, local designs (pp. 338-350). San Francisco: Pfeiffer Publishing.

Palloff, R. M., \& Pratt, K. (2007). Building online learning communities: Effective strategies for the virtual classroom. San Francisco: Jossey-Bass.

Patton, M.Q. (2002). Qualitative research \& evaluation methods (3rd ed.). Thousand Oaks: Sage Publications.

Posner, G. J., \& Rudnitsky, A. N. (2001). Course design: A guide to curriculum development for teachers (6th ed.). Addison Wesley Longman, Inc.

Reeves, T. C., Herrington, J., \& Oliver, R. (2002). Authentic activities and online learning. In A. Goody, J. Herrington, \& M. Northcote (Eds.), Quality Conversations: Research and Development in Higher Education, 25, 562-567. Jamison, ACT: HERDSA.

Reeves, T. C., Herrington, J., \& Oliver, R. (2005). Design research: A socially responsible approach to instructional technology research in higher education. Journal of Computing in Higher Education, 16(2), 97-116.

Rovai, A. P., \& Jordan, H. (2004). Blended learning and sense of community: A comparative analysis with traditional and fully online graduate courses. The International Review of Research in Open and Distance Learning, 5(2). Retrieved from http://www.irrodl.org/index.php/irrodl/article/view/192/795

Rowley, K., Bunker, E., \& Cole, D. (2002). Designing the right blend: Combining online and onsite for optimal training results. Performance Improvement, 41(4), 26-36.

Savery, J. R., \& Duffy, T. M. (1995). Problem-based learning: An instructional model and its constructivist framework. In B. Wilson (Ed.), Constructivist learning environments: Case studies in instructional design (pp. 135-148). Englewood Cliffs, NJ: Educational Technology Publications.

Singh, H. (2003). Building effective blended learning programs. Educational Technology, 43(6), 51-54.

So, H.-J., \& Bonk, C. J. (2010). Examining the roles of blended learning approaches in computersupported collaborative learning (CSCL) environments: A delphi study. Educational Technology \& Society, 13(3), 189-200.

Tyler, R. W. (1949). Basic principles of curriculum and instruction. Chicago: University of Chicago Press.

van Manen, M. (1990). Researching lived experience: Human science for an action sensitive pedagogy. Albany, N.Y.: State University of New York Press.

Voos, R. (2003). Blended learning: What is it and where might it take us? Sloan-C View, 2(1). Retrieved from http://www.aln.org/publications/view/v2n1/blended $1 . h t m$

Wagner, E. D. (1994). In support of a functional definition of interaction. The American Journal of Distance Education, 8(2), 6-26.

Willis, J. W. (2008). Qualitative research methods in education and educational technology. Charlotte, NC: Information Age Publishing.

Woo, Y., \& Reeves, T. C. (2007). Meaningful interaction in web-based learning: A social constructivist interpretation. Internet and Higher Education, 10, 15-25.

Woods, R., Baker, J.D., \& Hopper, D. (2004). Hybrid structures: Faculty use and perception of web-based courseware as a supplement to face-to-face instruction. The Internet and Higher Education, 7(4), 281297. 
Australasian Journal of Educational Technology, 2013, 29(1).

Corresponding author: Nuray Gedik,ngedik@akdeniz.edu.tr

Australasian Journal of Educational Technology (C) 2013.

Please cite as: Gedik, N., Kiraz, E., \& Ozden, M. Y. (2013). Design of a blended learning environment: Considerations and implementation issues. Australasian Journal of Educational Technology. 29(1), $1-19$. 